\title{
Direct Determination of Gold in Rock Samples Using Collision Cell Quadrupole ICP-MS
}

\author{
Seong A. Yim, ${ }^{1,2}$ Man Sik Choi, ${ }^{2,3}$ Jung Sun Chae ${ }^{3}$ \\ ${ }^{1}$ Division of Emergency Preparedness and Environment, Korea Institute of Nuclear Safety, Daejeon, Korea \\ ${ }^{2}$ Department of Ocean Environmental Sciences, Chungnam National University, Daejeon, Korea \\ ${ }^{3}$ Graduate School of Analytical Science and Technology, Chungnam National University, Daejeon, Korea
}

\begin{abstract}
This study investigated the determination of $\mathrm{Au}$ in rock samples using collision cell quadrupole inductively coupled plasma mass spectrometry (ICP-MS). It is essential to remove various interferents using a collision cell because polyatomic ions such as ${ }^{181} \mathrm{Ta}^{16} \mathrm{O}^{+}$and ${ }^{180} \mathrm{Hf}^{16} \mathrm{O}^{1} \mathrm{H}^{+}$can interfere with the direct determination of monoisotopic ${ }^{197} \mathrm{Au}$ when using ICP-MS. The addition of oxygen as a reaction gas removed isobaric interferents by transforming $\mathrm{TaO}^{+}$and $\mathrm{HfOH}^{+}$to $\mathrm{TaO}_{2}{ }^{+}$, $\mathrm{TaO}_{3}{ }^{+}$, and $\mathrm{HfO}_{2} \mathrm{H}^{+}, \mathrm{HfO}_{3} \mathrm{H}^{+}$, respectively, in the cell without significant $\mathrm{Au}^{+}$loss. The ion kinetic energy effect (IKEE) due to the potential difference between the plasma and the hexapole affected the reactions in the cell. Au and interfering ions were very sensitive to cell bias voltage $(\mathrm{Vc})$ at constant plasma potential $(\mathrm{Vp})$ and quadrupole bias voltage $(\mathrm{Vq})$. Under the condition of hot plasma, the transmission of ions was promoted, and the maximum Au signal intensity was $50 \%$ greater than under normal conditions. At $\mathrm{Vc}>7 \mathrm{~V}, \mathrm{TaO}^{+}$ions were removed to background level. Optimized conditions for real sample analysis were obtained by introducing $\mathrm{He}$ as an additional collision gas in hot plasma. $\mathrm{TaO}^{+}$ions were removed to background level at $\mathrm{He}$ flow rates above $0.6 \mathrm{~mL} \mathrm{~min}^{-1}$, and the Au signal remained high. The detection limit (three times the standard deviation of the blank) of this method was $3.06 \mathrm{pg} \mathrm{g}^{-1}$. The results for reference materials (STM-1 and DGPM-1) and spiked samples showed good agreement between specified and measured concentrations.
\end{abstract}

Key words: Collision cell, Ion kinetic energy effect, Cell bias voltage, Quadrupole bias voltage

\section{Introduction}

$\mathrm{T}$ o explore geochemistry and to conduct increasingly sophisticated Au deposit assessment procedures, highquality analytical data are necessary, especially for $\mathrm{Au}$ concentrations near or below the cut-off grade. Estimates of crustal abundance are on the order of 0.003-0.004 parts per million [1], and it is very difficult to quantify $\mathrm{Au}$ accurately at such low levels. Analytical methods for $\mathrm{Au}$ detection include a fire assay [2-5] with instrumental neutron activation (INAA) [2-6], aqua regia dissolution $[2,5,6]$ with atomic absorption (AA) such as graphite furnace atomic absorption (GFAA), aqua regia dissolution with inductively

Correspondence to: Man Sik Choi; e-mail: mschoi@cnu.ac.kr coupled plasma mass spectrometry (ICP-MS), and a combination of cyanidation [2] and AA, GFAA, or ICP-MS. Additional methods include ion exchange [7, 8], preconcentration, and vapor generation with inductively coupled plasma atomic emission spectrometry (ICP-AES) [9].

Aqua regia dissolution/ICP-MS is very simple and cost effective. Furthermore, it can quantitatively recover gold in rock samples [6] due to the excellent detection ability of ICP/MS. However, aqua regia dissolution without a separation procedure suffers from several polyatomic interferences during ICP-MS analysis. Oxides and hydroxides of matrix metals such as ${ }^{181} \mathrm{Ta}^{16} \mathrm{O}^{+}$and ${ }^{180} \mathrm{Hf}^{16} \mathrm{O}^{1} \mathrm{H}^{+}$interfere with the monoisotope ${ }^{197} \mathrm{Au}$ [6, 10-12]. Although this can be corrected using mathematical equations that include ${ }^{181} \mathrm{Ta}^{16} \mathrm{O}^{+} / 181 \mathrm{Ta}^{+}$and ${ }^{180} \mathrm{Hf}^{16} \mathrm{O}^{1} \mathrm{H}^{+} / 180 \mathrm{Hf}^{+}$ratios, the results for ${ }^{197} \mathrm{Au}$ analysis have large errors because both Ta and $\mathrm{Hf}$ concentrations are thousands of times higher than $\mathrm{Au}$ in rock 
samples. Therefore, for the direct determination of ${ }^{197} \mathrm{Au}$ using ICP-MS, it is essential to remove interferents using a technique such as a collision cell procedure.

Collision cell technology uses collision/reaction gases such as $\mathrm{H}_{2}, \mathrm{He}, \mathrm{O}_{2}, \mathrm{NH}_{3}$, or $\mathrm{CH}_{4}$ to remove polyatomic interferents in ICP-MS through collisional removal or transformation to other interfering ions. For $\mathrm{Au}$ analysis, several studies have suggested the use of $\mathrm{O}_{2}$ as a reaction gas for the transformation of $\mathrm{TaO}^{+}$and $\mathrm{HfOH}^{+}$to heavier compounds such as $\mathrm{TaO}_{2}{ }^{+}$and $\mathrm{HfO}_{2} \mathrm{H}^{+}[11,13-16]$, respectively. However, optimization of $\mathrm{Au}$ analysis by removing interfering ions using collision cell technology for rock samples with very low Au concentrations and high Ta and Hf concentrations has not yet been reported.

This study investigated the effects of collision/reaction gases and instrumental parameters controlling ion energy in hexapole collision cell ICP-MS and determined Au concentrations directly in rock samples containing high Ta and $\mathrm{Hf}$ concentrations without pre-concentration procedures.

\section{Experimental}

\section{Background on Collision Cell Technology}

Ions produced in the plasma enter the interface, where they are extracted under vacuum into a collision cell that is positioned before the analyzer quadrupole. Collision/reaction gases such as $\mathrm{H}_{2}, \mathrm{He}, \mathrm{O}_{2}, \mathrm{NH}_{3}$, or $\mathrm{CH}_{4}$ are then bled into the cell, which consists of a multipole (a quadrupole, hexapole, or octapole), usually operated in radio frequency (rf)-only mode. The rf-only field does not separate the masses like a traditional quadrupole but instead focuses the ions, which then collide and react with molecules of the collision/reaction gas. By a number of different ion-molecule collision and reaction mechanisms, polyatomic interferents such as argides (e.g., $\mathrm{Ar}_{2}^{+}, \mathrm{ArCl}^{+}$, $\mathrm{ArN}^{+}, \mathrm{ArH}^{+}, \mathrm{ArC}^{+}$) and oxides (e.g., $\mathrm{CaO}^{+}, \mathrm{ZnO}^{+}, \mathrm{CeO}^{+}$, $\mathrm{ZrO}^{+}, \mathrm{TaO}^{+}$) derived from the plasma gas, matrix components, or an acid used to dilute a solution are converted to harmless, non-interfering species, or the target ions are converted to other ions. The target ions, free from the interference, then emerge from the collision cell and enter the quadrupole analyzer for normal mass separation $[11,14]$.

Kinetic energy discrimination (KED) is the key to distinguishing the collision product ions from target ions. This is achieved by setting the collision cell bias slightly less positive than the quadrupole bias. This means that the collision product ions, having the same energy as the cell bias, are discriminated against and rejected, while the analyte ions, having a higher energy than the cell bias, are transmitted [13, 17-23]. Because polyatomic ions collide with collision gas more frequently than with analyte ions, most of the analytes maintain a higher energy than the collision product ions.

Early work by Tuner et al. using $\mathrm{He}$ gas alone in a collision cell resulted in the successful attenuation of the argide ions $\mathrm{Ar}_{2}^{+}, \mathrm{ArCl}^{+}, \mathrm{ArO}^{+}$, and $\mathrm{Ar}^{+}$, enabling the quantification of $\mathrm{Se}, \mathrm{As}, \mathrm{Fe}$, and $\mathrm{Ca}$ [24]. Feldmann et al. reduced ${ }^{40} \mathrm{Ar}^{40} \mathrm{Ar}^{+}$ions, allowing the detection of ${ }^{80} \mathrm{Se}$ at sub-part per billion levels [26].

$\mathrm{Du}$ and Houk also described the attenuation of metal oxides $\left(\mathrm{ZrO}^{+}, \mathrm{CeO}^{+}, \mathrm{LaO}^{+}, \mathrm{SmO}^{+}, \mathrm{HoO}^{+}, \mathrm{YbO}^{+}\right.$, and $\left.\mathrm{WO}^{+}\right)$ by dissociation using $\mathrm{H}_{2}$ gas [19]. While most polyatomic ions are weakly bound, $\mathrm{TaO}^{+}$(dissociation energy $=$ $\sim 750 \mathrm{~kJ} \mathrm{~mol}^{-1}$ ) and $\mathrm{HfOH}^{+}$are strongly bound and do not easily dissociate into single ions, although sufficient collision gas can be supplied [14]. Furthermore, Ta and Hf exist in much higher concentrations than $\mathrm{Au}$ in rock, and collision is not able to break polyatomic ions that interfere with $\mathrm{Au}^{+}$; excess collision gas removes $\mathrm{Au}^{+}$.

Fortunately, $\mathrm{TaO}^{+}$and $\mathrm{HfOH}^{+}$with higher internal energies than $\mathrm{Au}^{+}$can react with $\mathrm{O}_{2}$ gas and are easily transformed into $\mathrm{TaO}_{2}{ }^{+}, \mathrm{TaO}_{3}{ }^{+}$and $\mathrm{HfO}_{2} \mathrm{H}^{+}, \mathrm{HfO}_{3} \mathrm{H}^{+}$, respectively, but $\mathrm{Au}^{+}$ does not react with $\mathrm{O}_{2}$ gas and is not transformed [11, 13-16]. As a result, $\mathrm{O}_{2}$ reaction gas in a collision cell makes it possible to distinguish polyatomic interferents such as $\mathrm{TaO}^{+}$and $\mathrm{HfOH}^{+}$ from an analyte, in this case $\mathrm{Au}^{+}$.

\section{Instrumentation}

In this study, a quadrupole-based ICP-MS instrument (Thermo Elemental, X7, Manchester, UK) with a hexapole collision cell operated in Korea Basic Science Institute was used (Scheme 1). The collision cell was positioned between the extraction lens and ion lens, followed by the quadrupole. The ions formed in the argon plasma at atmospheric pressure were accelerated by applying a negative potential $(-497 \mathrm{~V})$ to the extraction lens and were transported through the hexapole from the region behind the skimmer cone into the quadrupole mass analyzer. $\mathrm{O}_{2}$ was introduced into the collision cell as a reaction gas and He was used as a collision gas. These gases were controlled by mass flow controllers using the software for X-7. Two types of plasma modes were used to make two kinds of plasma potentials: one is a standard mode which is made using normal plasma conditions, and the other is a hot plasma mode which use metal screen between quartz torch and load coil to reduce the plasma potential and to make a narrow ion energy distribution [25]. The Meinhard concentric nebulizer and a quartz spray chamber cooled to $3{ }^{\circ} \mathrm{C}$ using a Peltier cooling system were used for sample introduction. To reduce the high memory effect of $\mathrm{Au}, 10 \%$ hydrochloric acid was used as a cleaning solution [26]. Details of the instrumental components, typical operating conditions, and data acquisition parameters are given in Table 1.

\section{Reagents and Materials}

ICP-MS standard solutions were prepared by serial dilutions of $1000 \mu \mathrm{g} \mathrm{mL} \mathrm{m}^{-1}$ stock standard solution $(99.999 \%$; Anapure Ltd. Daejeon, Korea). High-purity deionized water (resistivity higher than $18 \mathrm{M} \Omega \mathrm{cm}^{-1}$ ) was obtained from a Milli-Q Plus water purifier (Millipore, Bedford, MA, USA). High-purity acids for sample pretreatment were purchased from Dongwoo Pure Chemicals (electronic grade; Iksan, 


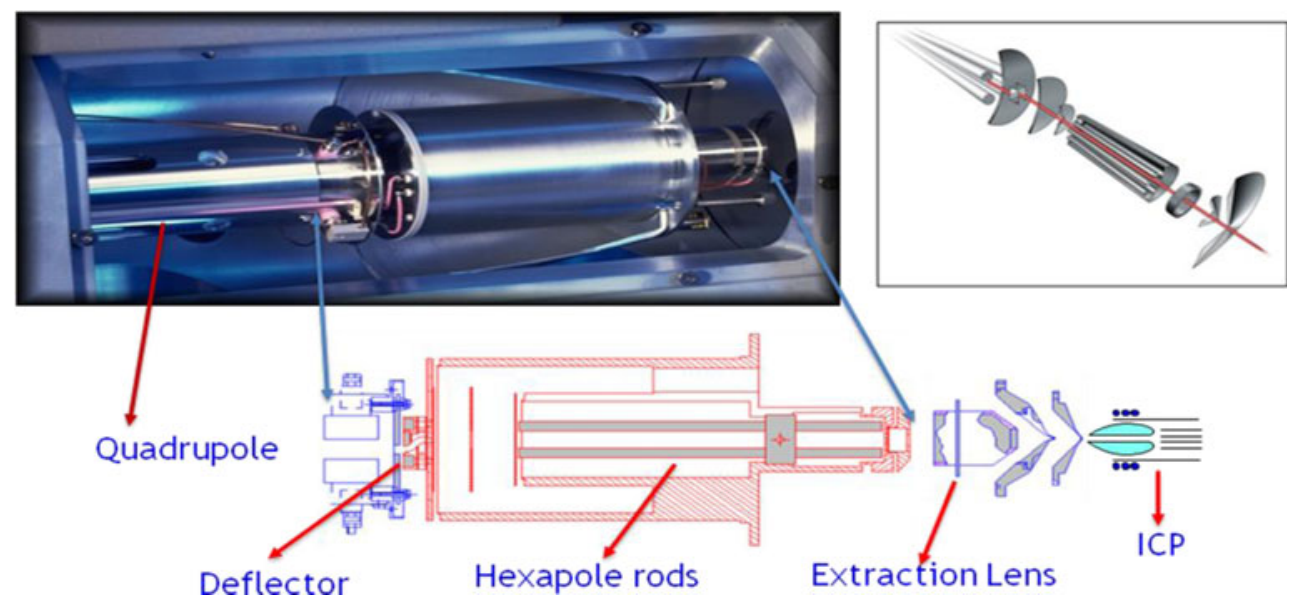

Scheme 1. Schematic diagram of hexapole collision cell QICP-MS

Korea), and $\mathrm{HNO}_{3}$ was purified using the Teflon two-bottle method for sub-boiling distillation in the laboratory. Reference materials STM-1 and DGPM-1 were purchased from the U.S. Geological Survey (Denver, CO, USA). STM-1 is the standard reference material of nepheline syenite containing $28 \pm 2 \mu \mathrm{g} \mathrm{g}^{-1} \mathrm{Hf}$ and $18.6 \pm 1.2 \mu \mathrm{g} \mathrm{g}^{-1} \mathrm{Ta}$, and DGPM-1 is a disseminated gold ore reference material containing $0.730 \pm 0.060 \mu \mathrm{g} \mathrm{g}^{-1}$ Au used to establish analytical accuracy for the determination of gold. All bottles used in this study were thoroughly pre-cleaned by soaking in 10\% hydrochloric acid for several days. $\mathrm{O}_{2}$ and $\mathrm{He}$ gases were obtained from Daeil Science (99.999\%; Daejeon, Korea).

\section{Sample Preparation \\ Spiked Samples}

Different amounts of Au standard solution were spiked in $10 \mathrm{ng} \mathrm{g}^{-1} \mathrm{Ta}$ and $\mathrm{Hf}$ mixed solutions to prepare seven spiked

Table 1. Optimum operating parameters used for Au measurement using collision cell quadrupole ICP/MS

\begin{tabular}{|c|c|c|}
\hline \multicolumn{3}{|l|}{ ICP } \\
\hline Spray chamber temperature $\left({ }^{\circ} \mathrm{C}\right)$ & \multicolumn{2}{|l|}{3} \\
\hline Sample uptake rate $\left(\mathrm{mL} \min ^{-1}\right)$ & \multicolumn{2}{|l|}{0.4} \\
\hline Forward power (W) & \multicolumn{2}{|l|}{1250} \\
\hline Reflected power (W) & \multicolumn{2}{|l|}{$<2$} \\
\hline \multicolumn{3}{|l|}{ Argon flow rate } \\
\hline Cooling gas $\left(\mathrm{L} \min ^{-1}\right)$ & \multicolumn{2}{|l|}{13.1} \\
\hline Auxiliary gas $\left(\mathrm{L} \mathrm{min}^{-1}\right)$ & \multicolumn{2}{|l|}{0.66} \\
\hline Nebulizer gas $\left(\mathrm{L} \mathrm{min}^{-1}\right)$ & \multicolumn{2}{|l|}{0.96} \\
\hline Collision cell & Standard mode & Hot plasma mode \\
\hline Oxygen gas $\left(\mathrm{mL} \min ^{-1}\right)$ & 0.4 & 0.4 \\
\hline Helium gas $\left(\mathrm{mL} \min ^{-1}\right)$ & - & 0.66 \\
\hline Cell bias voltage $(\mathrm{V})$ & 9.9 & 5.5 \\
\hline \multicolumn{3}{|l|}{ Ion optics } \\
\hline Extraction lens voltage $(\mathrm{V})$ & -497 & -733 \\
\hline Focus (V) & 20.3 & 15.9 \\
\hline Lens $1(\mathrm{~V})$ & 4.2 & -2.3 \\
\hline Lens $2(\mathrm{~V})$ & -157.5 & -57.2 \\
\hline Lens 3 (V) & -174.5 & -144.1 \\
\hline Quadrupole bias voltage (V) & 1.0 & -2.0 \\
\hline
\end{tabular}

samples (Au concentration: $\sim 4.7-756 \mathrm{pg} \mathrm{g}^{-1}$ ), which resulted in $\sim 12-2,000 \mathrm{Ta} / \mathrm{Au}$ and $\mathrm{Hf} / \mathrm{Au}$ ratios.

\section{Reference Materials}

Reference materials were mixed at STM-1:DGPM-1 weight ratios of 1:1, 1:2, 1:3, 1:4, and 1:5. All mixed materials were dried sufficiently in desiccators. Approximately $0.2 \mathrm{~g}$ of mixed material was put in a Teflon digestion vessel (60 mL; Savillex Co., MN, USA), and then $4 \mathrm{~mL}$ aqua regia, $2 \mathrm{~mL} \mathrm{Hf}$, and $1 \mathrm{~mL} \mathrm{HClO}_{4}$ were added. After the mixed materials were decomposed entirely by heating on a hot plate at $150{ }^{\circ} \mathrm{C}$ overnight,

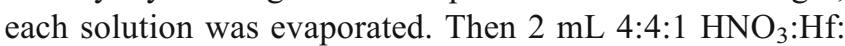
$\mathrm{HClO}_{4}$ mixed acid was added and heated at $150{ }^{\circ} \mathrm{C}$ overnight. After this solution was evaporated, residues were dissolved in $5 \% \mathrm{HNO}_{3}$ and diluted to $200 \mathrm{~g}$ using $5 \% \mathrm{HNO}_{3}$. This solution was filtered and introduced to the ICP-MS.

\section{Results and Discussion}

\section{Optimization of Instrumental Conditions}

Using a collision cell ICP-MS to analyze $\mathrm{Au}$ in rock samples, interferents such as $\mathrm{TaO}^{+}$and $\mathrm{HfOH}^{+}$induced from the sample matrix were removed by reaction with $\mathrm{O}_{2}$ and collision with $\mathrm{He}$. Instrumental conditions, including $\mathrm{O}_{2}$ and $\mathrm{He}$ gas flow rates, ion energy effects with respect to plasma potential, collision cell bias, and quadrupole bias, were optimized to obtain the maximum Au signal and minimum interferents.

\section{Effect of $\mathrm{O}_{2}$ Reaction Gas}

Only $\mathrm{O}_{2}$ gas was introduced into the collision cell for this investigation to determine the effect of $\mathrm{O}_{2}$ reaction gas using $1 \mathrm{ng} \mathrm{g}^{-1} \mathrm{Au}, 50 \mathrm{ng} \mathrm{g}^{-1} \mathrm{Ta}$, and $50 \mathrm{ng} \mathrm{g}^{-1}$ Hf solutions (Figures 1 and 2). Before adding $\mathrm{O}_{2}$ gas, $\mathrm{TaO}^{+}$existed at an intensity of about $0.7 \%$ of that of $\mathrm{Ta}^{+}$. At $\mathrm{O}_{2}$ flow 
(a)

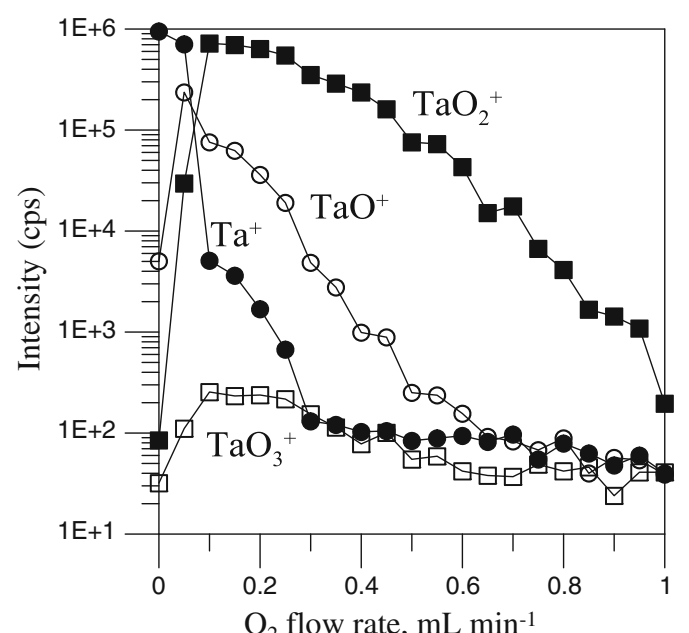

(b)

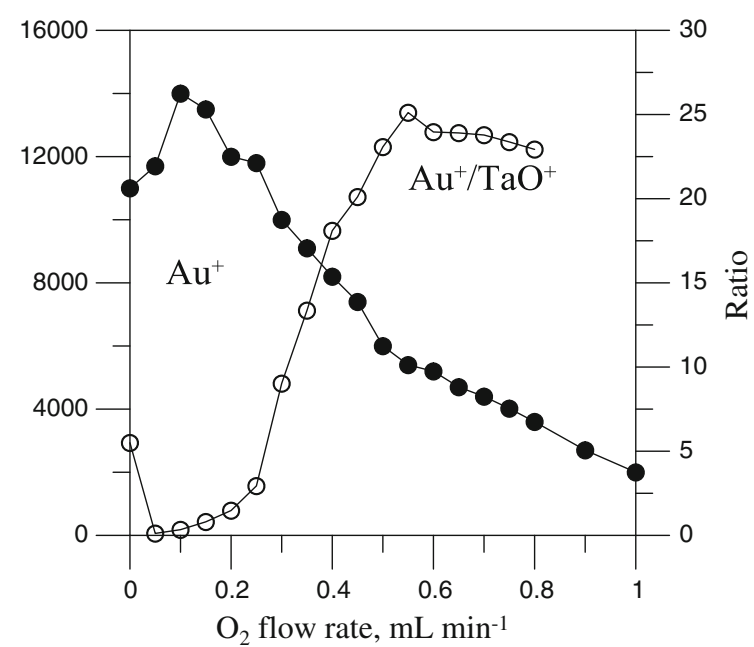

Figure 1. Influence of $\mathrm{O}_{2}$ flow rate on (a) $\mathrm{Ta}^{+}$and Ta oxide species for the introduction of $50 \mathrm{ng} \mathrm{g}^{-1} \mathrm{Ta}^{+}$solution and (b) $\mathrm{Au}^{+}$for the introduction of $1 \mathrm{ng} \mathrm{g}^{-1}$ Au solution and the calculated ratio of $\mathrm{Au}^{+}$to $\mathrm{TaO}^{+}$from $\mathrm{Au}^{+}$and $\mathrm{TaO}^{+}$intensities measured by introduction of $1 \mathrm{ng} \mathrm{g}^{-1}$ Au solution and $50 \mathrm{ng} \mathrm{g}^{-1}$ Ta solution, respectively. Cell bias voltage $=9.9 \mathrm{~V}$, quadrupole bias voltage $=1.0 \mathrm{~V}$

rates $<0.05 \mathrm{~mL} \min ^{-1}$, all Ta oxides increased immediately, and $\mathrm{TaO}^{+}$was the major oxide ion. At increased $\mathrm{O}_{2}$ flow rates, $\mathrm{Ta}^{+}$ions reacted with $\mathrm{O}_{2}$ rapidly and transformed into $\mathrm{TaO}^{+}, \mathrm{TaO}_{2}{ }^{+}$, and $\mathrm{TaO}_{3}{ }^{+}$, but $\mathrm{TaO}$ also transformed into $\mathrm{TaO}_{2}{ }^{+}$. Thus, $\mathrm{TaO}_{2}{ }^{+}$was the major $\mathrm{Ta}$ species at $\mathrm{O}_{2}$ flow rates $>0.1 \mathrm{~mL} \mathrm{~min}{ }^{-1}$.

Before adding $\mathrm{O}_{2}$ gas, $\mathrm{HfOH}^{+}$existed at an intensity of about $0.07 \%$ that of $\mathrm{Hf}^{+}$. The reaction of $\mathrm{Hf}^{+}$ions with $\mathrm{O}_{2}$ showed a similar trend as those of $\mathrm{Ta}^{+}$and $\mathrm{TaO}^{+}$ions with $\mathrm{O}_{2}$ (Figure 2) but differed slightly because $\mathrm{Hf}^{+}$and $\mathrm{HfOH}+$ reacted with $\mathrm{O}_{2}$ and presumably residual $\mathrm{H}_{2} \mathrm{O}$ or $\mathrm{H}_{2}$, and then $\mathrm{Hf}^{+}$transformed into $\mathrm{HfO}_{2} \mathrm{H}^{+}$and $\mathrm{HfO}_{3} \mathrm{H}^{+}$via $\mathrm{HfOH}^{+}$. $\mathrm{HfO}_{2} \mathrm{H}^{+}$remained as the major Hf-species ion at increased $\mathrm{O}_{2}$ gas flow rates.

$\mathrm{Au}^{+}$increased rapidly with $\mathrm{O}_{2}$ flow rates $<0.1 \mathrm{~mL} \mathrm{~min}{ }^{-1}$ and then decreased gradually with increasing $\mathrm{O}_{2}$ flow rates. The decrease in the $\mathrm{Au}^{+}$signal was due to collision with $\mathrm{O}_{2}$ rather than reaction. Excess $\mathrm{O}_{2}$ also removed many ions by collision. As shown in Figure 3, the reactivity of Ta differed from that of $\mathrm{Au}$ with $\mathrm{O}_{2}$. When the mixed solution (a)

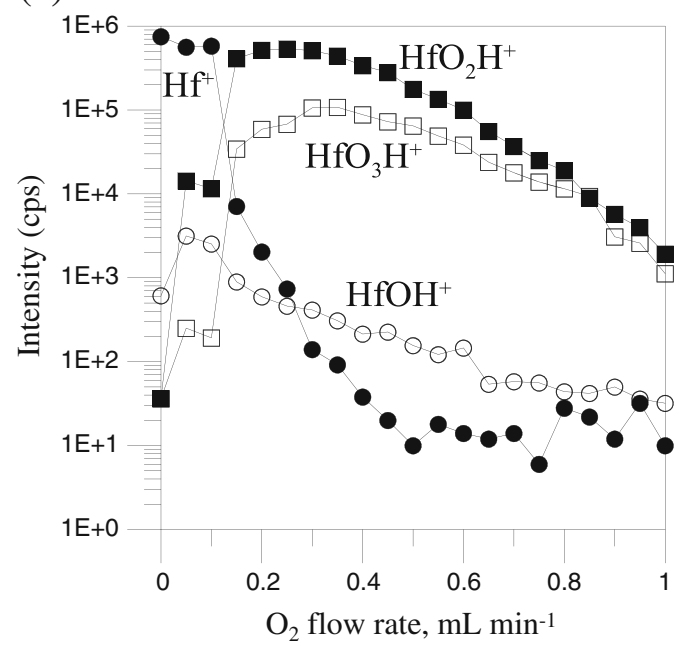

(b)

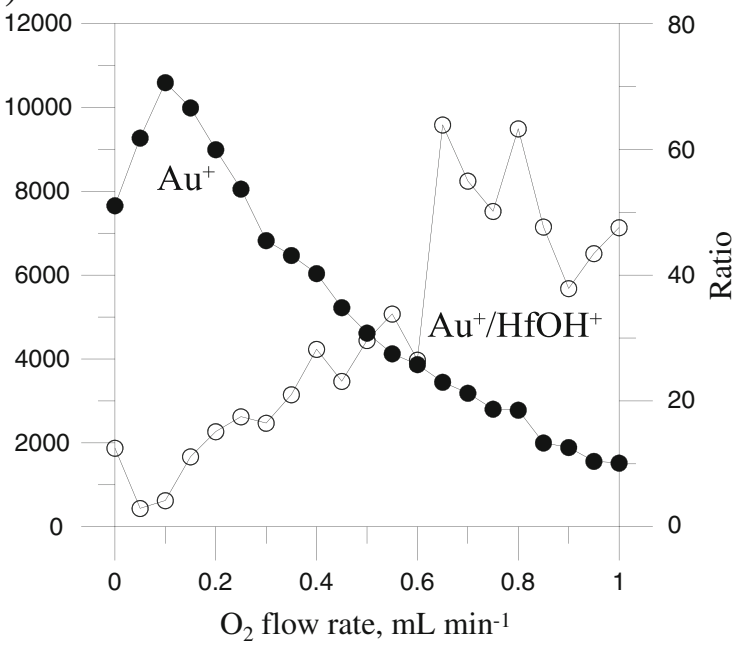

Figure 2. Influence of $\mathrm{O}_{2}$ flow rate on (a) $\mathrm{Hf}^{+}$and $\mathrm{Hf}$ oxide species for the introduction of $50 \mathrm{ng} \mathrm{g}^{-1} \mathrm{Hf}$ solution and (b) $\mathrm{Au}^{+}$for the introduction of $1 \mathrm{ng} \mathrm{g}^{-1} \mathrm{Au}$ solution and the calculated ratio of $\mathrm{Au}^{+}$to $\mathrm{HfOH}^{+}$from $\mathrm{Au}^{+}$and $\mathrm{HfOH}^{+}$intensities measured by introduction of $1 \mathrm{ng} \mathrm{g}^{-1} \mathrm{Au}$ solution and $50 \mathrm{ng} \mathrm{g}^{-1} \mathrm{Hf}$ solution, respectively. Cell bias voltage $=9.9 \mathrm{~V}$, quadrupole bias voltage $=1.0 \mathrm{~V}$ 


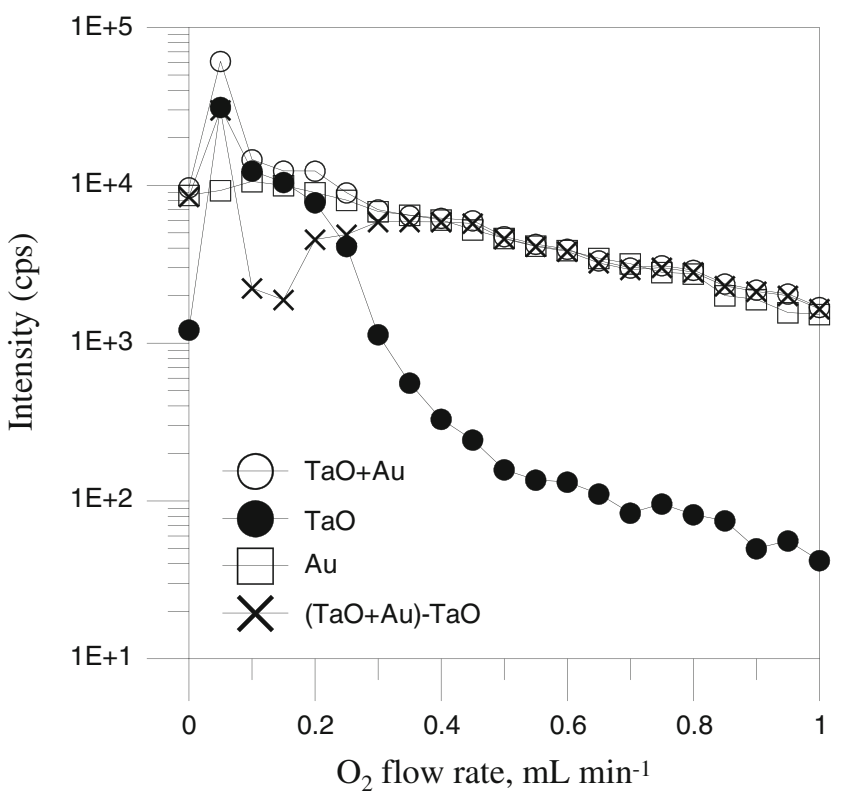

Figure 3. Intensity variation in $\mathrm{Au}^{+}$and $\mathrm{TaO}^{+}$measured by introduction of $1 \mathrm{ng} \mathrm{g}^{-1} \mathrm{Au}$ solution and $50 \mathrm{ng} \mathrm{g}^{-1} \mathrm{Ta}$ solution, respectively, as a function of $\mathrm{O}_{2}$ flow rate. Cell bias voltage $=9.9 \mathrm{~V}$, quadrupole bias voltage $=1.0 \mathrm{~V}$

containing $10 \mathrm{ng} \mathrm{g}^{-1}$ Ta and $1 \mathrm{ng} \mathrm{g}^{-1}$ Au was introduced, $\mathrm{Ta}^{+}$ was removed by reaction with $\mathrm{O}_{2}$, but $\mathrm{Au}^{+}$remained. Due to the sudden decrease in $\mathrm{TaO}^{+}$via reaction with $\mathrm{O}_{2}$, the intensity of mass number 197 was consistent with $1 \mathrm{ng} \mathrm{g}^{-1} \mathrm{Au}$ solution at $\mathrm{O}_{2}$ gas flow rates $>0.4 \mathrm{~mL} \mathrm{~min}^{-1}$. Thus, it is suggested that most $\mathrm{TaO}^{+}$ions were transformed into other oxides by reaction with $\mathrm{O}_{2}$, but $\mathrm{Au}^{+}$was affected by collision rather than reaction.

\section{Effect of Relative Ion Energy}

The effects of ion energy in a collision cell ICP-MS are key determinants of oxide removal from an analyte. The input ion energy, as determined by the potential difference between the plasma and hexapole, affects the reactions in the collision cell. This is termed the ion kinetic energy effect (IKEE) [13]. If the quadrupole bias voltage $(\mathrm{Vq})$ is more positive than the cell bias voltage $(\mathrm{Vc})$, another ion energy effect, kinetic energy discrimination (KED), which is defined as an exclusion of slow ions formed in a cell, can be applied. In this study, discrimination/rejection of interfering ions $\left(\mathrm{TaO}^{+}\right.$and $\left.\mathrm{HfOH}^{+}\right)$with a lower energy than $\mathrm{Vq}$ was considered as the removal mechanism of interfering ions in addition to transformation into other oxides $\left(\mathrm{TaO}_{2}{ }^{+}\right.$, $\mathrm{TaO}_{3}{ }^{+}, \mathrm{HfO}_{2} \mathrm{H}^{+}$, and $\mathrm{HfO}_{3} \mathrm{H}^{+}$) by reaction with $\mathrm{O}_{2}$. Therefore, ion energy effects depend on the combination of the plasma potential $(\mathrm{Vp})$ and $\mathrm{Vc}$ as well as the combination of $\mathrm{Vc}$ and $\mathrm{Vq}$. $\mathrm{TaO}^{+}, \mathrm{HfOH}^{+}$, and $\mathrm{Au}^{+}$signals showed unique trends with respect to each factor. To identify the influence of each factor on ion energy effects, $\mathrm{Au}^{+} / \mathrm{TaO}^{+}$and $\mathrm{Au}^{+} / \mathrm{HfOH}^{+}$ratios and the $\mathrm{Au}^{+}$signal were varied by changing each factor under constant operating conditions.
Specifically, a hot plasma with a shield torch at normal $\mathrm{rf}$ power was applied to change the plasma offset potential $(\mathrm{Vp})$, which can be used to evaluate the influences of IKEE on $\mathrm{TaO}^{+}$and $\mathrm{HfOH}^{+}$removal and the Au signal.

\section{Cell Bias Voltage}

Figure 4 shows the measured $\mathrm{Au}^{+} / \mathrm{TaO}^{+}$ratio and $\mathrm{Au}^{+}$signal as a function of $\mathrm{Vc}$. Because $\mathrm{Vp}$ and $\mathrm{Vq}$ were constant, the variation in $\mathrm{Vc}$ indicates the changes in the potentials between the plasma and the collision cell $(\Delta \mathrm{Vp}-\mathrm{c})$ and between the collision cell and the quadrupole $(\Delta V c-q)$. Therefore, the variation in $\mathrm{Vc}$ changes ion kinetic energy, which affects $\mathrm{TaO}^{+}$and $\mathrm{HfOH}^{+}$reactivity with $\mathrm{O}_{2}$ and on the $\mathrm{Au}^{+}$signal. Figure $4 \mathrm{a}$ shows that as $\mathrm{Vc}$ increased toward positive values, $\mathrm{Au}^{+}$sensitivity and $\mathrm{Au}^{+} / \mathrm{TaO}^{+}$ratio increased markedly under constant $\mathrm{Vp}(\mathrm{rf}$ power $=1250 \mathrm{~W})$ and $\mathrm{Vq}$ $(1.0 \mathrm{~V})$. This trend was observed only when $\mathrm{Vc}$ was $>\mathrm{Vq}$. When $\mathrm{Vc}<\mathrm{Vq}$, most signals were reduced and defocused because most ions could not overcome the potential barrier between the collision cell and the quadrupole. When $\mathrm{Vc}<\mathrm{Vq}$ $(1.0 \mathrm{~V})$, the energy of the ions in the cell was insufficient to propel the ions into the mass analyzer. When $\mathrm{Vc}>\mathrm{Vq}(1.0 \mathrm{~V})$, no potential barrier existed between the collision cell and the quadrupole; thus, most ions were transmitted into the quadrupole, and the $\mathrm{Au}^{+}$signal increased sharply. When $\mathrm{Vc}>7.5 \mathrm{~V}$, $\mathrm{Au}^{+}$intensities decreased because $\Delta \mathrm{Vp}-\mathrm{c}$ decreased too much. Figure $4 \mathrm{~b}$ shows the variation in $\mathrm{TaO}^{+} / \mathrm{Ta}^{+}$and $\mathrm{TaO}_{2}^{+} / \mathrm{TaO}^{+}$ with $\mathrm{Vc}$. In this case, an increasing $\mathrm{Vc}$ indicates a decreasing $\Delta \mathrm{Vp}-\mathrm{c}$. Oxide formation might depend strongly on $\Delta \mathrm{Vp}-\mathrm{c}$, and reactivity increased at high Vc. That is, IKEE had a significant influence on reactivity with $\mathrm{O}_{2}$. As $\mathrm{Vc}$ increased relative to $\mathrm{Vp}$, the average kinetic energy of the ions decreased, and reaction with $\mathrm{O}_{2}$ in the cell accelerated. Thus, $\mathrm{TaO}^{+} / \mathrm{Ta}^{+}$ and $\mathrm{TaO}_{2}{ }^{+} / \mathrm{TaO}^{+}$ratios increased. This can be explained by the fact that $\mathrm{Ta}^{+}$transformed into $\mathrm{TaO}^{+}$, which subsequently transformed into $\mathrm{TaO}_{2}{ }^{+}$. $\mathrm{TaO}^{+} / \mathrm{Ta}^{+}$decreased at $\mathrm{Vc}>4 \mathrm{~V}$ because most $\mathrm{TaO}^{+}$ions transformed into $\mathrm{TaO}_{2}{ }^{+}$due to high reactivity. Although the $\mathrm{Au}$ signal decreased when $\mathrm{Vc}$ was $>$ $7.5 \mathrm{~V}$, the $\mathrm{Au}^{+} / \mathrm{TaO}^{+}$ratio increased continuously (Figure 4a). This result is due to the same reason discussed above.

These trends were independent of $\mathrm{O}_{2}$ flow rate. The $\mathrm{O}_{2}$ flow rate influenced $\mathrm{Vc}$ but not the signal intensity or reaction degree.

\section{Influence of Hot Plasma on Cell Bias Voltage (Vc)}

The ionization efficiency of Au in ICP is only 51\% [27]. Therefore, $\mathrm{Au}$ intensity is lower than that of other elements at the same concentration. The result shown in Figure 4c was obtained in hot plasma using a shield torch. Polyatomic ions as well as analyte ions produced in argon plasma are enhanced to a greater extent in hot plasma than in normal plasma. As shown in Figure 4c, hot plasma enhanced $\mathrm{Au}^{+}$ and $\mathrm{TaO}^{+}$intensities, but changed the $\mathrm{Vc}$ values with the highest intensities to the lower values. Furthermore, the peak 
(a)

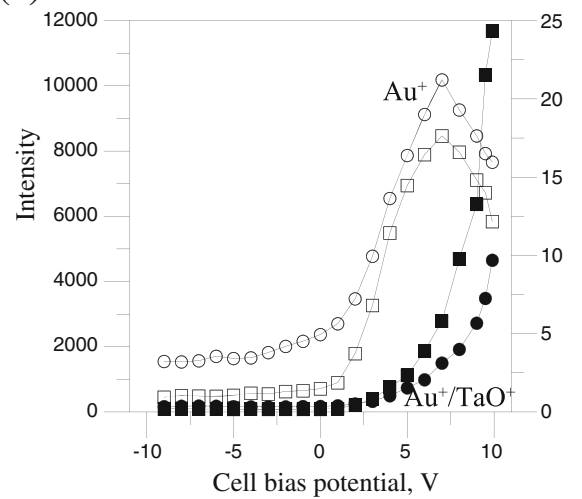

(b)

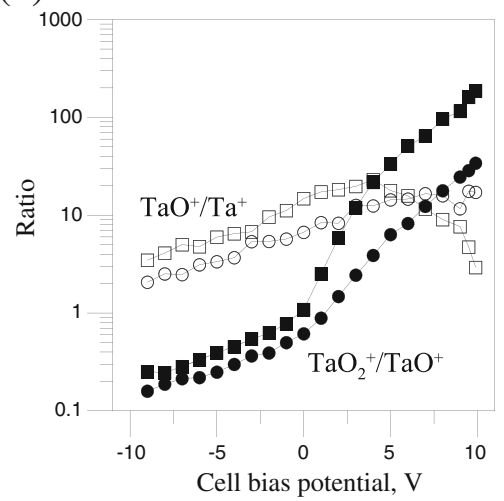

(c)

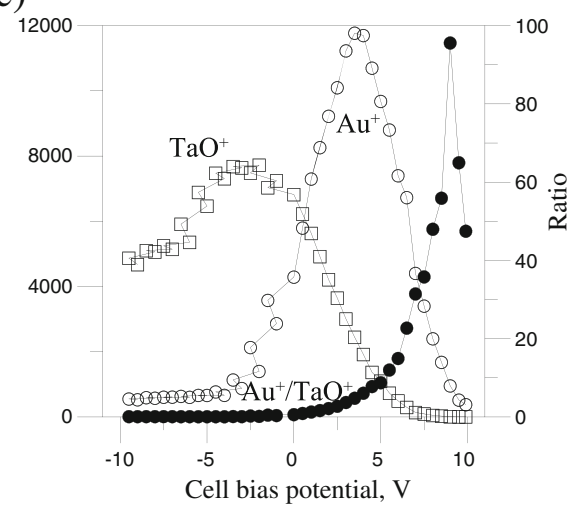

Figure 4. (a) Influence of hexapole cell bias voltage on $\mathrm{Au}^{+}$(open) and $\mathrm{Au}^{+} / \mathrm{TaO}^{+}$(closed) ratios for introduction of $1 \mathrm{ng} \mathrm{g}^{-1} \mathrm{Au}$ and $50 \mathrm{ng} \mathrm{g}^{-1}$ Ta solution under two conditions: $0.25 \mathrm{mLmin}^{-1} \mathrm{O}_{2}$ (circle) and $0.4 \mathrm{mLmin}^{-1} \mathrm{O}_{2}$ (square). (b) Influence of cell bias voltages on $\mathrm{TaO}^{+} / \mathrm{Ta}^{+}$(open) and $\mathrm{TaO}_{2}{ }^{+} / \mathrm{TaO}^{+}$(closed) ratios for introduction of $10 \mathrm{ng} \mathrm{g}^{-1}$ Ta solution under two conditions: $0.25 \mathrm{mLmin}^{-1} \mathrm{O}_{2}$ (circle) and $0.4 \mathrm{mLmin}^{-1} \mathrm{O}_{2}$ (square). (c) Influence of cell bias voltages on $\mathrm{Au}^{+}$(open) and $\mathrm{Au}^{+} / \mathrm{TaO}^{+}$ (closed) ratios for the introduction of $1 \mathrm{ng} \mathrm{g}^{-1} \mathrm{Au}$ and $10 \mathrm{ng} \mathrm{g}^{-1}$ Ta solutions under the conditions of hot plasma combined with a shield torch, if power $=1250 \mathrm{~W}$, quadrupole bias voltage $=-2.0 \mathrm{~V}$, and $\mathrm{O}_{2}$ flow rate $=0.4 \mathrm{mLmin}^{-1}$

of $\mathrm{Au}^{+} / \mathrm{TaO}^{+}$ratio, which was FOUR times greater than the maximum value in normal plasma (Figure 4a), was found at $\mathrm{Vc}=9 \mathrm{~V}$.

$\Delta \mathrm{Vp}-\mathrm{c}$ can be lowered by decreasing $\mathrm{Vp}$ or increasing Vc. In this study, the maximum $\mathrm{Au}^{+}$intensity was achieved at $\mathrm{Vc}=7.5 \mathrm{~V}$ in normal plasma and at $\mathrm{Vc}=4.5 \mathrm{~V}$ in hot plasma. Also, the optimum $\mathrm{Vq}$ value shifted from 1.0 to $-2.0 \mathrm{~V}$. Therefore, lower $\mathrm{Vp}$ in hot plasma shifted the $\mathrm{Vc}$ and $\mathrm{Vq}$ with the highest intensity to lower values. Since the $\mathrm{Vc}$ could be controlled between $-10 \mathrm{~V}$ and $10 \mathrm{~V}$ in our instrument, the peak of $\mathrm{Au}^{+} / \mathrm{TaO}^{+}$ratio could not be observed in normal plasma (Figure 4a). On the other hand, when the hot plasma was used, the peak of the ratio was found at $V c=9$ due to the lowered $V p$. It was not obvious whether IKEE was promoted or not in hot plasma than in normal plasma. However, if the maxima of both intensity and ratio in hot plasma were assumed to be found at $3 \mathrm{~V}$ lowered $\mathrm{Vc}$ than in normal plasma, $\mathrm{Au}^{+} / \mathrm{TaO}^{+}$ratio at $\mathrm{Vc}=$ $10 \mathrm{~V}$ in normal plasma (Figure 4a) was applicable to that at $\mathrm{Vc}=7 \mathrm{~V}$ in hot plasma (Figure 4c). Since two values for the ratio were just similar to each other and about 25 , it might be suggested that hot plasma enhanced the intensity and changed the Vc with the highest intensity, but did not promote the IKEE than normal plasma. Although the maximum $\mathrm{Au}^{+} / \mathrm{TaO}^{+}$ratio was found at $\mathrm{Vc}=9 \mathrm{~V}$, the optimum $\mathrm{Vc}$ was chosen as $\mathrm{Vc}=5.5 \mathrm{~V}$ because $\mathrm{Au}^{+}$intensity was too low at $\mathrm{Vc}=9 \mathrm{~V}\left(<1000 \mathrm{cps}\right.$ in $1 \mathrm{ng} \mathrm{g}^{-1}$ Au solution $)$.

\section{Quadrupole Bias Voltage}

The influence of quadrupole bias voltage on $\mathrm{Au}^{+}$and $\mathrm{Au}^{+} /$ $\mathrm{TaO}^{+}$ratios was investigated at a constant $\mathrm{Vc}$ of $+9.9 \mathrm{~V}$. Variation in Vq influenced reactivity in the cell. Figure 5 shows the $\mathrm{Au}^{+} / \mathrm{TaO}^{+}$ratios and $\mathrm{Au}^{+}$sensitivity as a function of $\mathrm{Vq}$. With $\mathrm{Vq}>6 \mathrm{~V}$, ions, including $\mathrm{Au}^{+}$and polyatomic ions, were not able to overcome the energy barrier between the quadrupole and the collision cell; thus, all signals decreased to background level. $\mathrm{Au}^{+}$sensitivity and $\mathrm{TaO}^{+}$ reactivity with $\mathrm{O}_{2}$ were unaffected at $\mathrm{Vq}<6 \mathrm{~V}$. Therefore, analyte sensitivity was optimized at $\mathrm{Vq}<\mathrm{Vc}$.

\section{Influence of He Collision Gas on Optimized Analysis of Au in Real Samples}

Instrument optimization for maximum $\mathrm{Au}^{+}$signal and minimum $\mathrm{TaO}^{+}$ions was necessary to measure $\mathrm{Au}$ in a real sample using collision cell ICP-MS. Although hot plasma is effective for achieving a high $\mathrm{Au}^{+}$signal under optimized

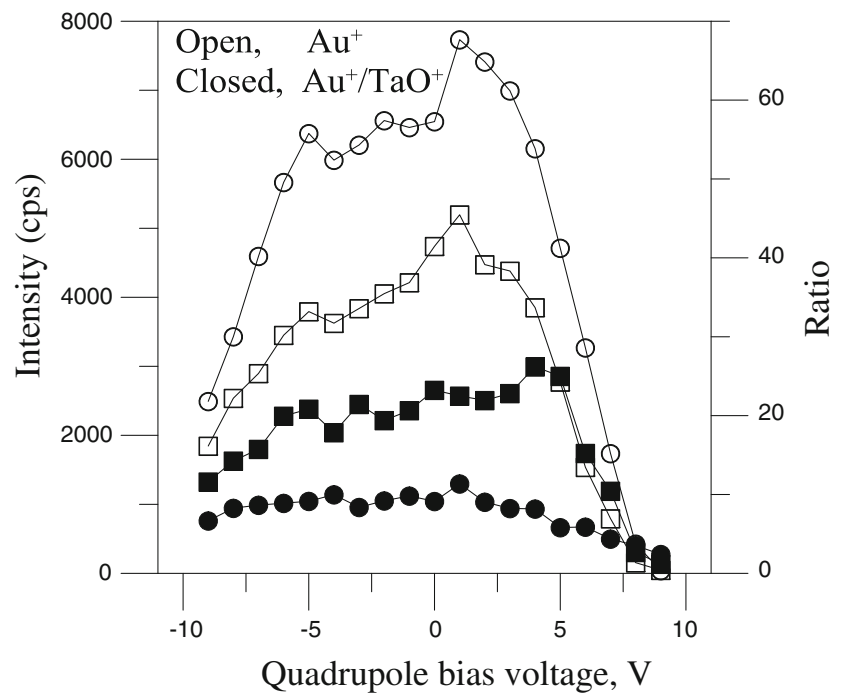

Figure 5. Influence of quadrupole bias voltage on $\mathrm{Au}^{+}$ (open) and $\mathrm{Au}^{+} / \mathrm{TaO}^{+}$ratios (closed) for the introduction of $1 \mathrm{ng} \mathrm{g}^{-1} \mathrm{Au}$ and $50 \mathrm{ng} \mathrm{g}^{-1} \mathrm{Ta}$ solutions under two conditions: $0.25 \mathrm{~mL} \mathrm{~min}^{-1} \mathrm{O}_{2}$ (circle) and $0.4 \mathrm{~mL} \mathrm{~min}^{-1} \mathrm{O}_{2}$ (square). Cell bias voltage $=9.9 \mathrm{~V}$ in normal plasma and rf power $=1250 \mathrm{~W}$ 


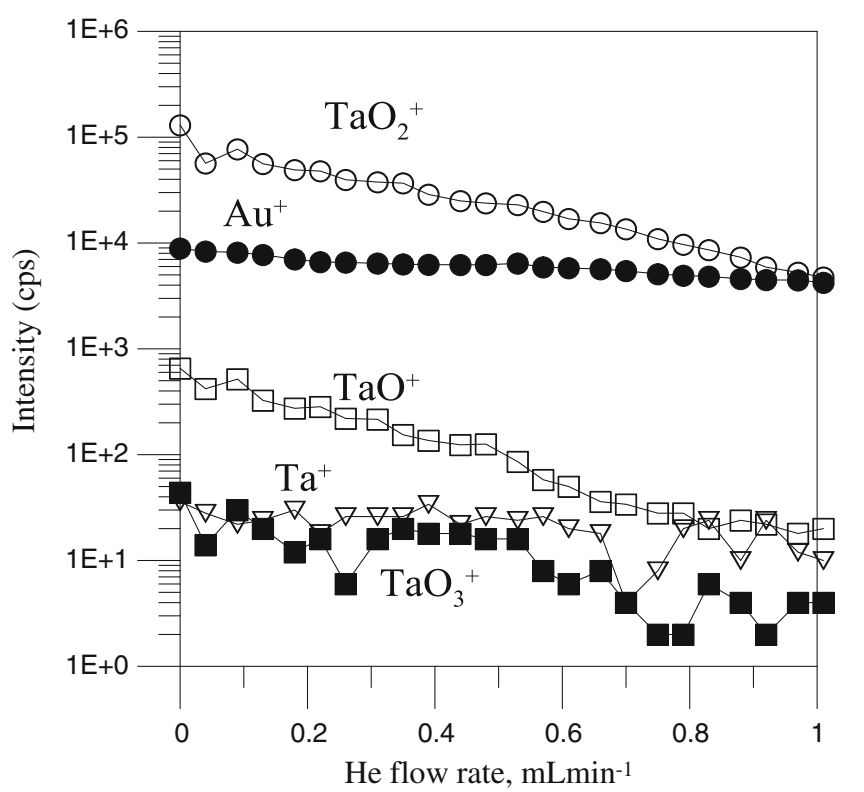

Figure 6. Influence of He flow rate on $\mathrm{Au}^{+}, \mathrm{Ta}^{+}$, and $\mathrm{Ta}$ oxide species for the introduction of $1 \mathrm{ng} \mathrm{g}^{-1} \mathrm{Au}$ and $10 \mathrm{ng} \mathrm{g}^{-1} \mathrm{Ta}$ solutions under conditions of hot plasma combined with a shield torch, if power $=1250 \mathrm{~W}$, cell bias voltage $=5.5 \mathrm{~V}$, quadrupole bias voltage $=-2.0 \mathrm{~V}$, and $\mathrm{O}_{2}$ flow rate $=$ $0.4 \mathrm{~mL} \mathrm{~min}^{-1}$

conditions, some $\mathrm{TaO}^{+}$ions were not removed and remained unreacted. Residual $\mathrm{TaO}^{+}$ions were removed by collision with $\mathrm{He}$ gas (Figure 6). Collision gas plays an important role in removing residual $\mathrm{TaO}^{+}$ions after reaction with $\mathrm{O}_{2}$ gas. Although $\mathrm{O}_{2}$ gas can play a role of collision gas as well as a reaction gas, it can reduce $\mathrm{Au}^{+}$and $\mathrm{TaO}^{+}$too much before complete removal of polyatomic interferents because it is a large-sized molecule. In the other hand, a smaller collision gas such as $\mathrm{He}$ can collide more efficiently with larger polyatomic ions such as $\mathrm{TaO}^{+}$than with smaller ions such as monoatomic $\mathrm{Au}^{+}$. He collision gas not only enhanced the $\mathrm{Au}^{+}$ signal but also effectively removed $\mathrm{TaO}^{+}$ions in the hot plasma with a shield torch. As shown in Figure 6, $\mathrm{TaO}^{+}$ions were

Table 2. Measured concentration of $\mathrm{Au}$ spiked in $10 \mathrm{ng} \mathrm{g}^{-1} \mathrm{Ta}$ and $\mathrm{Hf}$ mixed solutions using collision cell QICP-MS under conditions of hot plasma combined with a shield torch, $\mathrm{O}_{2}$ flow rate $=0.4 \mathrm{~mL} \mathrm{~min}{ }^{-1}, \mathrm{He}$ flow rate $=0.66 \mathrm{~mL} \mathrm{~min}^{-1}$, cell bias voltage $=5.5 \mathrm{~V}$, and quadrupole bias voltage $=-2.0 \mathrm{~V}$

\begin{tabular}{lccc}
\hline $\begin{array}{c}\text { Sample } \\
\text { No. }\end{array}$ & $\begin{array}{c}\text { Spiked Concentration } \\
\mathrm{C}_{\text {spiked }}, \mathrm{pg} \mathrm{g}^{-1}\end{array}$ & $\begin{array}{c}\text { Observed Concentration } \\
\mathrm{C}_{\text {observed }}, \mathrm{pg} \mathrm{g}^{-1}\end{array}$ & $\begin{array}{c}\mathrm{C}_{\text {observed }} \\
\mathrm{C}_{\text {spiked }}\end{array}$ \\
\hline 1 & 4.72 & $6.29 \pm 3.57$ & 1.33 \\
2 & 9.91 & $14.0 \pm 2.4$ & 1.41 \\
3 & 14.8 & $20.0 \pm 2.7$ & 1.32 \\
4 & 19.0 & $18.6 \pm 2.9$ & 0.98 \\
5 & 38.4 & $37.9 \pm 3.6$ & 0.99 \\
6 & 76.2 & $80.5 \pm 5.7$ & 1.05 \\
7 & 756 & $670 \pm 30$ & 0.89 \\
\hline
\end{tabular}

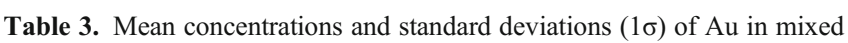
reference materials (STM-1 and DGPM-1) using collision cell QICP-MS under conditions of hot plasma using a shield torch, $\mathrm{O}_{2}$ flow rate = $0.4 \mathrm{~mL} \mathrm{~min}{ }^{-1}$, He flow rate $=0.66 \mathrm{~mL} \mathrm{~min}^{-1}$, cell bias voltage $=5.5 \mathrm{~V}$, and quadrupole bias voltage $=-2.0 \mathrm{~V}$

\begin{tabular}{lccccc}
\hline \multirow{2}{*}{$\begin{array}{c}\text { STM- : } \\
\text { DGPM-1 }\end{array}$} & $\begin{array}{c}\text { Observed conc. of Au, } \\
\mathrm{C}_{\text {observed }}, \mathrm{ng} \mathrm{g}^{-1}\end{array}$ & \multicolumn{3}{c}{ Specified conc. $\left(\mathrm{ng} \mathrm{g}^{-1}\right)$} & \multirow{2}{*}{$\mathrm{C}_{\text {observed }}$ ' } \\
\cline { 3 - 5 } & & $\mathrm{Au}$ & $\mathrm{HF}$ & $\mathrm{Ta}$ & \\
\hline $1: 1$ & $0.437 \pm 0.006$ & 0.398 & 13.8 & 9.36 & 1.10 \\
& $0.530 \pm 0.005$ & 0.409 & 13.8 & 9.36 & 1.29 \\
& $0.593 \pm 0.015$ & 0.491 & 13.9 & 9.46 & 1.21 \\
$1: 2$ & $0.504 \pm 0.008$ & 0.477 & 8.35 & 5.67 & 1.06 \\
& $0.436 \pm 0.011$ & 0.426 & 8.53 & 5.79 & 1.02 \\
& $0.317 \pm 0.003$ & 0.400 & 8.30 & 5.63 & 0.79 \\
$1: 3$ & $0.537 \pm 0.012$ & 0.529 & 6.98 & 4.73 & 1.02 \\
& $0.471 \pm 0.009$ & 0.536 & 6.91 & 4.69 & 0.88 \\
& $0.487 \pm 0.021$ & 0.532 & 6.88 & 4.67 & 0.92 \\
$1: 4$ & $0.513 \pm 0.005$ & 0.562 & 5.55 & 3.76 & 0.91 \\
& $0.489 \pm 0.015$ & 0.577 & 5.56 & 3.77 & 0.85 \\
& $0.487 \pm 0.009$ & 0.588 & 5.55 & 3.76 & 0.83 \\
$1: 5$ & $0.397 \pm 0.005$ & 0.513 & 4.16 & 2.82 & 0.77 \\
& $0.505 \pm 0.011$ & 0.563 & 4.27 & 2.89 & 0.90 \\
& $0.410 \pm 0.008$ & 0.509 & 4.18 & 2.84 & 0.81 \\
\hline
\end{tabular}

removed to background level at He flow rates above $0.6 \mathrm{~mL} \mathrm{~min}^{-1}$, and the $\mathrm{Au}^{+}$signal remained high.

\section{Sample Analysis \\ Analysis of Spiked Samples}

Table 2 shows the analysis results of Au spiked in mixed solutions of $10 \mathrm{ng} \mathrm{g}^{-1} \mathrm{Ta}$ and Hf. Good agreement between spiked and measured $\mathrm{Au}$ concentrations was obtained in solutions with $\mathrm{Au}$ concentrations higher than $15 \mathrm{pg} \mathrm{g}^{-1} \mathrm{Au}$. The recovery of $\mathrm{Au}$ in spiked samples ranged from $89 \%$ to $106 \%$ (mean values for three measurements). For real samples with Au concentrations $<15 \mathrm{pg} \mathrm{g}^{-1} \mathrm{Au}$, recoveries were relatively high and ranged from $133 \%$ to $141 \%$.

\section{Analysis of Reference Materials}

Table 3 shows the analysis results of $\mathrm{Au}$ in mixed reference materials. Measured $\mathrm{Au}$ concentrations in mixed samples were similar to the crustal abundance, $3 \mathrm{ng} \mathrm{g}^{-1}$. For each sample, the counting standard deviation was $<4 \%$, and the ratios of the measured values to the specified values ranged from 0.77 to 1.29 .

\section{Conclusions}

This study demonstrated that the collision cell technique effectively eliminated ${ }^{181} \mathrm{Ta}^{16} \mathrm{O}^{+}$and ${ }^{180} \mathrm{Hf}^{16} \mathrm{O}^{1} \mathrm{H}^{+}$for $\mathrm{Au}$ analysis using quadrupole ICP-MS. Removal was achieved by adding $\mathrm{O}_{2}$ and $\mathrm{He}$ to the collision cell as a reaction gas and a buffer gas, respectively. The strong reactivity of major interfering molecular ions such as ${ }^{181} \mathrm{Ta}^{16} \mathrm{O}^{+}$and ${ }^{180} \mathrm{Hf}^{16} \mathrm{O}^{1} \mathrm{H}^{+}$towards $\mathrm{O}_{2}$ enabled the measurement of $\mathrm{Au}$. ${ }^{181} \mathrm{Ta}^{16} \mathrm{O}^{+}$and ${ }^{180} \mathrm{Hf}^{16} \mathrm{O}^{1} \mathrm{H}^{+}$were very unstable and highly 
reactive toward $\mathrm{O}_{2}$; thus, they were easily transformed into ${ }^{181} \mathrm{Ta}^{16} \mathrm{O}_{2}{ }^{+}$and ${ }^{180} \mathrm{Hf}^{16} \mathrm{O}_{2}{ }^{1} \mathrm{H}^{+}$, respectively. Furthermore, the difference in the probabilities of $\mathrm{Au}^{+}$and other interfering molecular ions colliding with $\mathrm{He}$ buffer gas enabled selective enhancement of the Au signal. The collision cell technique was very sensitive to the $\mathrm{O}_{2}$ flow rate and the cell bias. Excess $\mathrm{O}_{2}$ reaction gas and $\mathrm{He}$ buffer gas decreased the $\mathrm{Au}^{+}$signal as well as oxide signals; the $\mathrm{O}_{2}$ flow rate was optimized at $0.40 \mathrm{~mL} \mathrm{~min}{ }^{-1}$ and $\mathrm{He}$ at

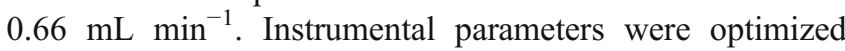
when cell bias was greater than the quadrupole bias voltage. Under these conditions, the collision cell quadrupole ICPMS technique further improved gold analysis without preconcentration. This study confirms the strong potential of collision cell quadrupole ICP-MS for Au analysis without elemental pre-separation or data correction to account for interfering molecular ions.

\section{Acknowledgments}

The authors thank Dr. H. S. Shin for permission to use the instrument of Korea Basic Science Institute. This work was mainly supported under Korea Institute of Nuclear Safety's project and partially National Research Foundation of Korea Grant (2009, University-Institute cooperation program) funded by the Korean Government (MEST).

\section{References}

1. Technical Resources Document-Extraction and beneficiation of ores and minerals: Gold, EPA 530-R-94-013; NTIS PB94-170-305, p. 185. U.S. EPA: Washington (1994)

2. Hoffman, E.L., Clark, J.R., Yeager, J.R.: Gold analysis - Fire assaying and alternative methods. Explor. Mining Geol. 7, 155-160 (1998)

3. Barefoot, R.R.: Determination of the precious metals in geological materials by inductively coupled plasma mass spectrometry. J. Anal. At. Spectrom. 13, 1077-1084 (1998)

4. Kim, B.H., Kim, Y.S., Kim, S.T.: Preconcentration method for platinum group metals. Anal. Sci. Technol. 14(6), 109-124 (2001)

5. Shibuya, E.K., Sarkis, J.E.S., Enzweiler, J., Jorge, A.P.S., Figueiredo, A.M.J.: Determination of platinum group elements and gold in geological materials using an ultraviolet laser ablation high-resolution inductively coupled plasma mass spectrometric technique. J. Anal. At. Spectrom. 13, 941-944 (1998)

6. Wemyss, R.B., Scott, R.H.: Simultaneous determination of platinum group metals and gold, in ores and related plant materials by inductively coupled plasma-optical emission spectrometry. Anal. Chem. 50(12), 1694-1697 (1978)

7. Tunceli, A., Turker, A.R.: Determination of gold in geological samples and anode slimes by atomic absorption spectrometry after preconcentration with Amberlite XAD-16 resin. Analyst 122, 239-242 (1997)

8. Jarvis, I., Totland, M.M., Jarvis, K.E.: Assessment of Dowex 1-X8based anion-exchange procedures for the separation and determination of ruthenium, rhodium, palladium, iridium, platinum, and gold in geological samples by inductively coupled plasma mass spectrometry. Analyst 122, 19-26 (1997)
9. Pohl, P., Zyrnicki, W.: Analytical features of Au, Pd, and Pt chemical vapor generation inductively coupled plasma atomic emission spectrometry. J. Anal. At. Spectrom 18, 798-801 (2003)

10. May, T.W., Wiedmeyer, R.H.: At. Spectrosc. 19(5), 150-155 (1998)

11. Simpson, L.A., Thomsen, M., Alloway, B.J., Parker, A.: A dynamic reaction cell (DRC) solution to oxide-based interferences in inductively coupled plasma mass spectrometry (ICP-MS) analysis of the noble metals. J. Anal. At. Spectrom. 16, 1375-1380 (2001)

12. Riepe, H.G., Gomez, M., Camara, C., Bettmer, J.: Feasibility studies on the suppression of $\mathrm{HfO}^{+}$mass interferences on platinum determination by inductively coupled plasma mass spectrometry (ICP-MS) by modification of the sample introduction system. J. Anal. At. Spectrom. 15, 507-511 (2000)

13. Dexter, M.A., Appelblad, P.K., Ingle, C.P., Batey, J.H., Reid, H.J., Sharp, B.L.: The effect of adventitious water in hexapole collision cell inductively coupled plasma mass spectrometry. J. Anal. At. Spectrom. 17, 183-188 (2002)

14. Jackson, G.P., King, F.L., Duckworth, D.C.: Efficient polyatomic interference reduction in plasma-source mass spectrometry via collision induced dissociation. J. Anal. At. Spectrom. 18, 10261032 (2003)

15. Baranov, V.I., Tanner, S.D.: A dynamic reaction cell for inductively coupled plasma mass spectrometry. J. Anal. At. Spectrom. 14, 11331142 (1999)

16. Dexter, M.A., Reid, H.J., Sharp, B.L.: The effect of ion energy on reactivity and species selectivity in hexapole collision/reaction cell ICPMS. J. Anal. At. Spectrom. 17, 676-681 (2002)

17. Hattendorf, B., Gunther, D.: Characteristics and capabilities of an ICPMS with a dynamic reaction cell for dry aerosols and laser ablation. $J$. Anal. At. Spectrom. 15, 1125-1131 (2000)

18. Thomas, R.: A beginner's guide to ICP-MS. Part IX-Mass analyzer: Collision/reaction cell technology. Spectroscopy 17(2), 42-48 (2002)

19. Du, Z., Houk, R.S.: Attenuation of metal oxide ions in inductively coupled plasma mass spectrometry with hydrogen in a hexapole collision cell. J. Anal. At. Spectrom. 15, 383-388 (2000)

20. Iglesias, M., Gilon, N., Poussel, E., Mermet, J.M.: Evaluation of an ICP-collision/reaction cell-MS system for the sensitive determination of spectrally interfered and non-interfered elements using the same gas conditions. J. Anal. At. Spectrom. 17, 1240-1247 (2002)

21. Marchante-Gayon, J.M., Feldmann, I., Thomas, C., Jakubowski, N.: Speciation of selenium in human urine by HPLC-ICP-MS with a collision and reaction cell. J. Anal. At. Spectrom. 16, 457-463 (2001)

22. O'Brien, S.E., Acon, B.W., Boulyga, S.F., Becker, J.S., Dietze, H.J., Montaser, A.: Reduction of molecular ion interferences with hexapole collision cell in direct injection nebulization-inductively coupled plasma mass spectrometry. J. Anal. At. Spectrom. 18, 230-238 (2003)

23. Boulyga, S.F., Becker, J.S.: Improvement of abundance sensitivity in a quadrupole-based ICP-MS instrument with a hexapole collision cell. $J$. Anal. At. Spectrom. 17, 1202-1206 (2002)

24. Tuner, P., Merren, T., Speakman, J., Haines, C.: Plasma Source Mass Spectrometry: New Developments and Applications, p. 28. Royal Society of Chemistry, Cambridge (1998)

25. Sabine Becker, J., Dietze, H.-J.: Application of double-focusing sector field ICP mass spectrometry with shielded torch using different nebulizers for ultratrace and precise isotope analysis of long-lived radionuclides. J. Anal. At. Spectrom. 14, 1493-1500 (1999)

26. Feldmann, I., Jakubowski, N., Thomas, C., Stuewer, D.: Application of a hexapole collision and reaction cell in ICP-MS. Part I: Instrumental aspects and operational optimization. Fresenius J. Anal. Chem 365, 415-421 (1999)

27. Chen, W., Wee, P., Brindle, I.D.: Elimination of the memory effects of gold, mercury, and silver in inductively coupled plasma atomic emission spectroscopy. J. Anal. At. Spectrom. 15, 409-413 (2000) 